
Family Medicine and
Community Health

\title{
Are we Athens or Florence? COVID-19 in historical context
}

\author{
Benjamin R Doolittle (D)
}

To cite: Doolittle BR. Are we Athens or Florence? COVID-19 in historical context. Fam Med Com Health 2021;9:e000811. doi:10.1136/fmch-2020-000811
Check for updates

(c) Author(s) (or their employer(s)) 2021. Re-use permitted under CC BY-NC. No commercial re-use. See rights and permissions. Published by BMJ.

Internal Medicine \& Pediatrics, Yale University, New Haven, Connecticut, USA

Correspondence to Dr Benjamin R Doolittle; benjamin.doolittle@yale.edu

\section{ABSTRACT}

We have been here before. In $430 \mathrm{BCE}$, a plague struck Athens, killing as much as $25 \%$ of the population. In $1347 \mathrm{CE}$, the bubonic plague afflicted western Europe for 4 years, killing as much as $50 \%$ of the population. The plague of Athens led to a collapse of their religion, cultural norms and democracy. In contrast, the bubonic plague led eventually to the Renaissance, a growth of art, science and humanism. As we contend with the COVID-19 global pandemic, will we become Athens or Florence?

In the year 430 BCE, a plague struck Athens (figure 1). ${ }^{1}$ Thucydides, the Greek historian, gave an eyewitness account in his work, The Peloponnesian War,

The disease began with a strong fever in the head and reddening and burning in the eyes; the first internal symptoms were that the throat and tongue became bloody and the breath unnatural and malodorous.... When it became established in the heart, it convulsed and produced every kind of evacuation of bile known to the doctors, accompanied by great discomfort. Most victims then suffered from empty retching, which induced violent convulsion: they abated after this for some sufferers, but only much later for others.... Most died about the seventh or the ninth day. ${ }^{2}$

Scholars have debated the aetiology of this epidemic. ${ }^{3}$ There is convincing evidence that the infection was a form of typhus based on paleopathological studies of dental records, but other compelling candidates include typhoid, plague or measles. ${ }^{3}$ City-states from Athens to Alexandria suffered. Twenty-five per cent of the population died. The impact had enormous repercussions. Their democratic government collapsed. Debauchery reigned among the citizenry. They raided the homes of the dead, committed acts of violence against each other, and turned their backs on established institutions. Their religion dissolved. Why entreat the gods when every petition and sacrifice went unanswered? The plague struck during the Peloponnesian
War, the great struggle between the autocratic Spartans and democratic Athenians. With a decimated populace, and a weakened morale, the Spartans crushed the Athenian league. Athens lost their superpower status for centuries. ${ }^{3}$

In the year 1347, a ship from the Black Sea sailed into the Sicilian port of Messina. There were stowaways on board: flea-infested rats carrying Yersinia pestis. Over the next few years, between $30 \%$ and $50 \%$ of the population died in Western Europe of the bubonic plague. ${ }^{4}$ The Italian writer Giovanni Boccaccio writes in his celebrated Decameron a first-hand account of the plague in Florence (figure 2),

It began both in men and women with certain swellings in the groin or under the armpit. They grew to the size of a small apple or an egg, more or less, and were vulgarly called tumours.... Soon after this the symptoms changed and black or purple spots appeared on the arms or thighs or any other part of the body, sometimes a few large ones, sometimes many little ones. These spots were a certain sign of death, just as the original tumour had been and still remained. ${ }^{6}$

And yet, the bubonic plague incited a complete reimaging of society. Old mores and customs broke down. The decline in population leads to a collapse of feudal society, the rise of an independent mercantile class and an increase in real wages. City-states stabilised and consolidated power. The economy reawakened. New ideas emerged-humanism and modern science. Michelangelo carved David. Leonardo sketched his flying machine. The devastation of society created space for the Renaissance. ${ }^{4}$

We have been here before. Pandemics are powerful forces which shape our culture for generations and dramatically influence the outcome of world events. The advent of the slavery in North America can be attributed to measles and smallpox. ${ }^{7}$ When the Spanish conquistadores invaded Hispaniola in the late 1400 s, these viruses decimated $98 \%$ of 


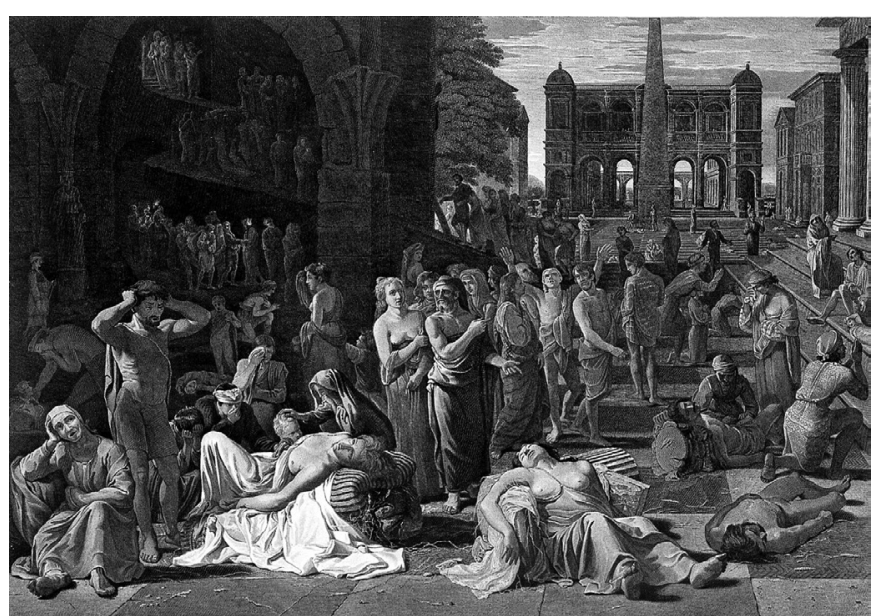

Figure 1 Plague in an ancient city by Michiel Sweerts, commonly regarded to depict the plague of Athens.

the local population, allowing a handful of conquistadores to conquer the island. Since the indigenous Arawak population was so diminished, the conquistadores began importing Africans to work the mines and cultivate sugar cane, begetting a centuries long tyranny. ${ }^{7}$ In 1812 , when Napoleon crossed the Niemen River into Russia, his Grand Armée numbered nearly half a million soldiers, the largest the world had ever seen. As he approached Moscow, an outbreak of dysentery killed 120 000, severely weakening his army. The only major battle against the Russian army-the Battle of Borodino-resulted in 30 000 French casualties. As Napoleon fled, an outbreak of typhus nearly decimated the rest of his army. Five months after invading, only 10000 soldiers survived to cross the border towards France, the vast majority dying of infectious disease, frigid temperatures and starvation. ${ }^{8} \mathrm{Had}$ Napoleon defeated Russia, the map of Europe would have looked vastly different. Our historic memory discounts the impact pandemics have had in shaping world events.

Pandemics bring out the best and worst in us. During the COVID-19 pandemic, we read daily examples of

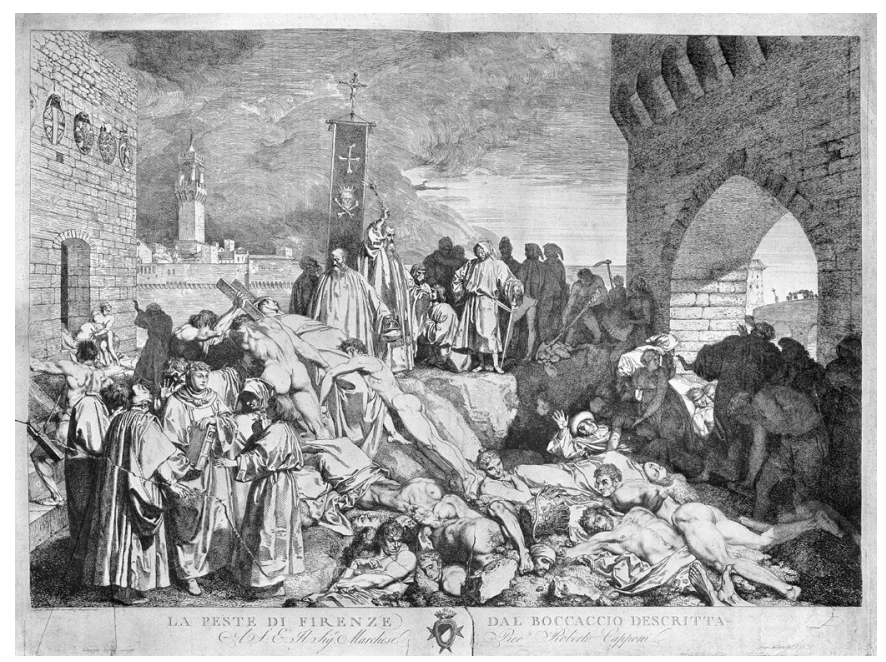

Figure 2 The plague of Florence in 1348 as depicted in Boccacio's Decameron, etching by Luigi Sabatelli. heroism by healthcare workers, sacrifice by neighbours, and generosity of strangers. ${ }^{9}$ During the bubonic plague, we read about the nameless priests and physicians who treated patients, often to their own demise. ${ }^{4}$ Pandemics also bring out in us a xenophobia and mean-spiritedness. In Athens, neighbours would steal funeral pyres from one another, heaping their own dead loved ones on their neighbours' wooden stacks and setting them ablaze. ${ }^{10}$ During the bubonic plague, officials blamed those on the fringes of society-notably the Jews. In 1349, the magistrates of Strasbourg blamed the 2000 Jews for the affliction of the plague. They led them to the Jewish cemetery and offered them an opportunity to convert. Half renounced their faith. Half were burned alive. ${ }^{11}$ The blame culture continues to pervade our society. Governments blame each other for spreading COVID-19. Pundits blame governments for a poorly coordinated response to the pandemic. Governments fault big pharma, the media and on and on.

Like other pandemics, the cracks in our society have grown larger and more apparent. COVID-19 has disproportionately struck the poor and ethnic minorities. A federal government, not informed by history, underestimated the threat, and failed to organise a robust national response. Some local governments marshalled resources that others did not have. A survey by Johns Hopkins has shown that the infection rate is three times higher in predominantly black counties than white, with a six times greater mortality. ${ }^{12}$ A Harvard study among patients with COVID-19 in Massachusetts showed that mortality was $40 \%$ higher in cities and towns with the largest minority concentration. Mortality was $14 \%$ higher in the most crowded cities compared with the least, and $9 \%$ higher in those with the worst poverty. ${ }^{13}$ The poor and disenfranchised suffer worse when pandemics hitwhether in 5th century BCE Athens, 14th century Florence or 21st century New York, Arizona or Texas. Here we are, again.

How will this time be different? How can we reimagine healthcare post COVID? Very quickly, in some states, we rolled out public health initiatives that flattened the curve. We incorporated telehealth into our ambulatory settings. We reconfigured wards in our hospitals. We went virtual with our educational programmes. We have become much nimbler than we ever thought we could be. What of this good stuff will we keep? Can we continue the innovation to solve the problems that we had pre-COVID? To become Florence, rather than Athens, we must continue this momentum of innovation.

We have been here before. There are deep forces at play in our society. The self-isolation has led to a cultural anxiety, a disconnect, that will need a transcendent vision to ameliorate. Rich institutions have emerged more powerful than ever, while the poor are even more vulnerable. Government response has been sluggish at best, with many putting dollars before human life. There are nagging questions for our society. Is this the demise of our society, or the beginning of another Renaissance? 
Will we remember our history? Will we become Athens or Florence?

Contributors I am the sole author of this essay. I conceived of this project, wrote and edited this essay. It is not under consideration at any other journal.

Funding The authors have not declared a specific grant for this research from any funding agency in the public, commercial or not-for-profit sectors.

Competing interests None declared.

Patient consent for publication Not required.

Provenance and peer review Not commissioned; externally peer reviewed.

Open access This is an open access article distributed in accordance with the Creative Commons Attribution Non Commercial (CC BY-NC 4.0) license, which permits others to distribute, remix, adapt, build upon this work non-commercially, and license their derivative works on different terms, provided the original work is properly cited, appropriate credit is given, any changes made indicated, and the use is non-commercial. See: http://creativecommons.org/licenses/by-nc/4.0/.

\section{ORCID iD}

Benjamin R Doolittle http://orcid.org/0000-0002-6922-6556

\section{REFERENCES}

1 Sweerts M. Plague in an ancient City. Available: https://commons. wikimedia.org/wiki/File:Plague in an Ancient_City_LACMA_AC1997. $10.1 \% 281$ of 2\%29.jpg [Accessed 23 Jun 2020].

2 Thucydides. The Peloponnesian war. Lattimore S, Translator. Cambridge, UK: Hackett, 1998: 98.
3 Cunha BA. The cause of the plague of Athens: plague, typhoid, typhus, smallpox, or measles? Infect Dis Clin North Am 2004;18:29-43.

4 Getz FM. Black death and the silver lining: meaning, continuity, and revolutionary change in histories of medieval plague. J Hist Biol 1991;24:265-89.

5 Sabatelli L. The plague of Florence. Available: https://commons. wikimedia.org/wiki/File:Boccaccio\%27s_\%27The_plague_of Florence_in_1348\%27_Wellcome_L0072270.jpg [Accessed 23 Jun 2020].

6 Boccaccio G. The Decameron of Giovanni Boccaccio. Aldington $R$ Translator. New York, NY: Dell, 1930: 31.

7 Snowden FM. Epidemics and society: from the black death to the present. New Haven, CT: Yale, 2020: 103.

8 Snowden FM. Epidemics and society: from the black death to the present. New Haven, CT: Yale, 2020: 140-67.

9 Cox CL. 'Healthcare heroes': problems with media focus on heroism from healthcare workers during the COVID-19 pandemic. J Med Ethics 2020;46:510-3.

10 Thucydides. The Peloponnesian war. Lattimore S, Translator. Cambridge, UK: Hackett, 1998: 100.

11 Cohn SK. The black death and the burning of Jews. Past Present 2007;196:3-36

12 Thebault R, Ba Tran A, Williams V. The coronavirus is infecting and killing black Americans at an alarmingly high rate. Washington post, 2020. Available: https://www.washingtonpost.com/nation/2020/04/ 07/coronavirus-is-infecting-killing-black-americans-an-alarminglyhigh-rate-post-analysis-shows/ [Accessed 23 Jun 2020].

13 Chen JT, Waterman PD, Krieger N. COVID-19 and the unequal surge in mortality rates in Massachusetts by population. Harvard center for population and development studies 9, 2020. Available: https://cdn1. sph.harvard.edu/wp-content/uploads/sites/1266/2020/05/20_jtc pdw_nk_COVID19_MA-excess-mortality_text_tables_figures_final_ 0509_with-cover-1.pdf 